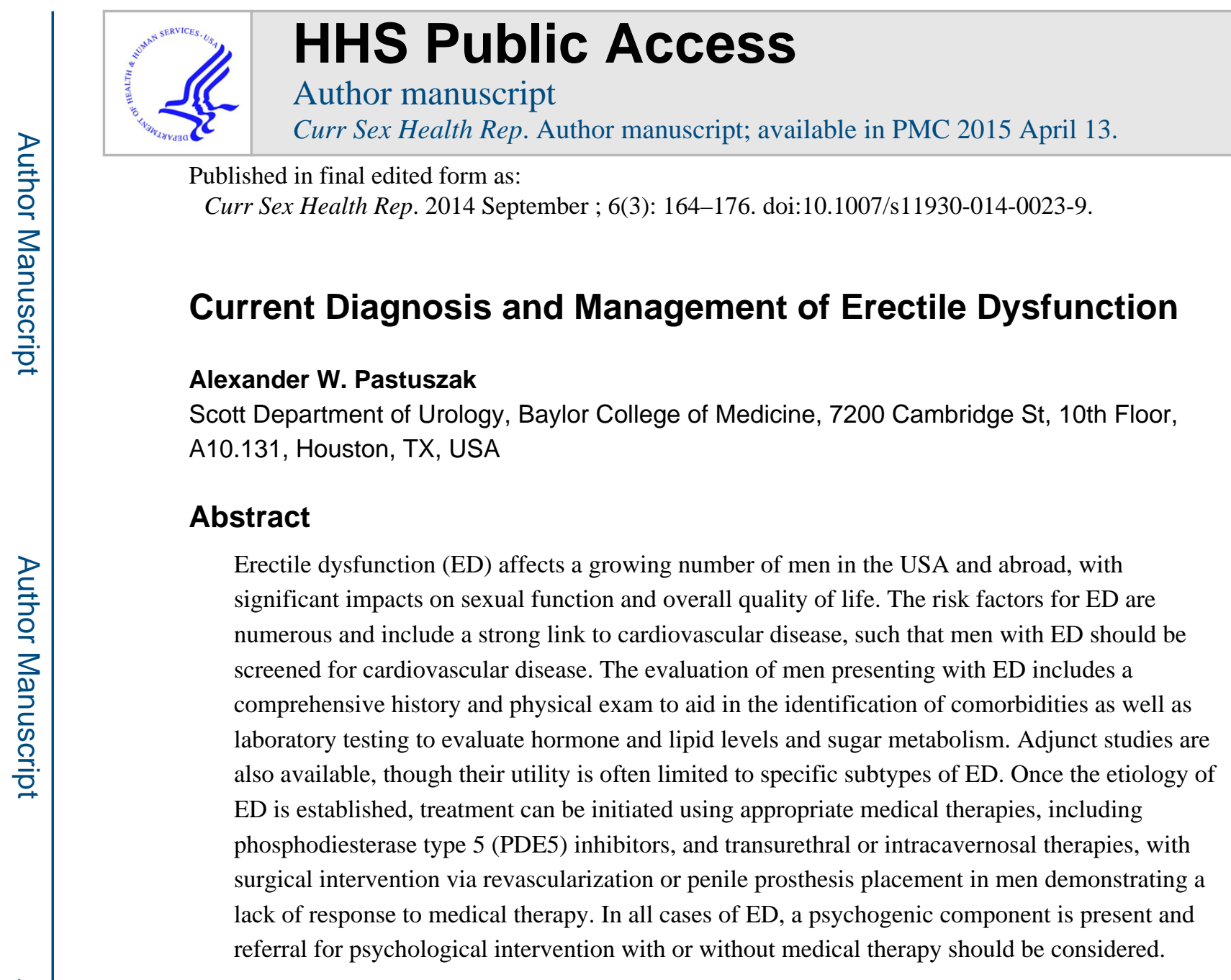

Keywords

Erectile dysfunction; Metabolic syndrome; Coronary artery disease; Hypogonadism; Penile prosthesis; PDE5 inhibitor; Intracavernosal injection; Intraurethral suppository; Penile revascularization; Acupuncture; Lower urinary tract symptoms; Benign prostatic hypertrophy

\title{
Introduction
}

While previously considered the domain of younger generations, recent large cohort studies have demonstrated that many aging men and women engage in sex, with close to $50 \%$ indicating that sex is important in their lives [1] and with 26-90\% of men and women aged $70-90$ years engaging in some form of sexual activity $[2,3]$. Notably, the most common sexual problem in US men is erectile difficulties (43\%) [3]. Furthermore, the determinants of sexual activity in aging men and women are numerous and variable, ranging from

\footnotetext{
(C) Springer Science+Business Media, LLC 2014 pastusza@bcm.edu.

This article is part of the topical collection on Male Sexual Dysfunction and Disorders

Compliance with Ethics Guidelines

Conflict of Interest

Alexander W. Pastuszak declares that he has no conflict of interest.

Human and Animal Rights and Informed Consent

This article does not contain any studies with human or animal subjects performed by the author.
} 
attitude, relationship satisfaction, marital status, physical and mental health, sleep satisfaction, and alcohol intake, necessitating a holistic approach to treatment $[4,5]$.

In men, sexual function declines over time, beginning during the fifth decade and affecting all domains of sexual health including desire, arousal, erectile function, and ejaculation/ orgasm [6-8]. Erectile dysfunction (ED) also negatively affects a man's relationships [9], emotional and psychological well-being [10,11], and partner relationships [12, 13]. Given the male desire to continue to engage in sex throughout life and the ramifications of ED on physical and psychological health, appropriate diagnosis and management of ED is of significance. Furthermore, in light of the multitude of available treatments and the expanding evidence base supporting an ever-growing list of risk factors and diagnostic and management modalities, review of the diagnosis and management of ED is timely.

\section{Physiology of Penile Erection}

To place the upcoming discussion into context, a brief review of the physiology of penile erection is prudent. Erection is a complex process involving hormonal, vascular, and neural systems, with significant psychological inputs as well. Normal male sexual function progresses through four stages: (1) desire, (2) erection, (3) ejaculation, and (4) detumescence, and both the erect and flaccid penile states progress through initiation and maintenance phases [14]. The pathways and hormones involved in erection are important for both penile erection and flaccidity and maintenance of penile cavernosal integrity $[15,16]$.

Erection is initiated by external stimuli acting through somatic and autonomic pathways (reviewed in [17]). Sensory receptors in the penile skin, glans, urethra, and corpus cavernosum coalesce into the dorsal nerves of the penis and the pudendal nerve, which enters the spinal cord at the S2-S4 nerve roots, with interfaces with the thalamus and sensory cortex. Activation of parasympathetic pathways prompts release of nitric oxide (NO) from cavernous nerves and endothelial cells, resulting in penile cavernosal smooth muscle relaxation, reducing peripheral arteriolar resistance and permitting blood inflow [16]. On a molecular level, NO release activates guanylyl cyclase, catalyzing the formation of cyclic guanosine monophosphate (cGMP), which in turn activates protein kinase $\mathrm{G}$ and leads to phosphorylation of potassium and calcium channels. This phosphorylation event then results in cellular hyperpolarization, reduced intracellular calcium, dissociation of myosin from actin, and subsequent smooth muscle relaxation. Cyclic adenosine monophosphate (cAMP) is a functionally similar mediator of smooth muscle relaxation activated by adenosine, calcitonin gene-related peptides, and prostaglandins [16].

Several factors contribute to penile detumescence. Norepinephrine, phenylephrine, and endothelin activate phospholipase $\mathrm{C}$, catalyzing the formation of inositol triphosphate and diacylglycerol and mediating an increase in intracytoplasmic calcium with subsequent smooth muscle contraction. Sympathetic discharge resulting in secretion of the above factors occurs soon after ejaculation, prompting detumescence [17]. Phosphodiesterase-mediated degradation of cGMP to GMP phosphodiesterase type 5 (PDE5) and cAMP to AMP (PDE4) can also prompt detumescence, and activation of Rho kinase phosphorylates and inhibits smooth muscle myosin phosphatase, preventing myofilament dephosphorylation and maintaining contraction [18]. 


\section{Risk Factors for Erectile Dysfunction}

Erectile dysfunction is the persistent inability to achieve or maintain penile erection satisfactory for sexual performance [19] and is the most common male sexual disorder, with $44 \%$ of men $60-69$ years old and up to $70 \%$ of men $\geq 70$ years old endorsing erectile difficulties; in men <40 years old, $\sim 5 \%$ endorse ED [20]. There are two major subtypes of ED: lifelong, in which erection cannot be achieved from the outset of sexual desire, and acquired, in which ED begins after a period of normal erectile and sexual activity. Each of these subtypes can have either psychogenic or organic contributors (Table 1), and both types may require intervention, particularly if lasting more than 3-6 months, given the link between ED and comorbidities that can worsen ED and a man's overall health.

Risk factors for ED are numerous (Table 2), with patients over 40 years old demonstrating a significant association between ED and cardiovascular risk factors including hyper-tension, dyslipidemia, diabetes mellitus (DM), coronary artery disease (CAD), and the metabolic syndrome. Based on meta-analysis of 45,558 participants from seven cohort studies, the relative risk (RR) of coronary events in men with ED is 1.47 (95\% confidence interval (CI) 1.29-1.66) [21]. More significantly, the RR of all-cause mortality in men with ED is 1.23 (95\% CI 1.02-1.48), indicating that ED is a marker for future morbidity and death. A study stemming from the Prostate Cancer Prevention Trial (PCPT) examining the effects of ED on CAD risk demonstrated that ED may be a harbinger of cardiovascular events, with 0.024 cardiovascular events per person year occurring in men with ED compared with 0.015 events in men without ED [22]. Other studies have demonstrated a 2-5-year interval between ED symptoms and the onset of cardiovascular symptoms and events [23, 24], and ED has been shown to be a risk factor for peripheral arterial disease and stroke [25, 26]. Thus, all men with ED should be screened for CAD, with evaluation for related comorbidities where appropriate.

Other risk factors for ED include obesity and sedentary lifestyle. Obesity, even in the absence of other ED risk factors, increases the risk of ED. In two large, cross-sectional population studies, elevated body mass index (BMI) predicted ED [27, 28]. Additional studies have identified obesity, insulin resistance, metabolic syndrome, and a lack of exercise as independent risk factors for ED [29, 30]. Furthermore, treatment of obesity and sedentary lifestyle improves ED, with approximately $30 \%$ of men who lost $10 \%$ or more of their body weight demonstrating an improvement in erectile function [31].

While the precise mechanism of obesity-related hypogonadism is unknown, it is likely linked to hormonal alterations, given the essential contribution of testosterone to normal erectile function [32,33]. A link between hypogonadism and ED has been forged in recent years with, conservatively, $12 \%$ of men with ED being concomitantly hypogonadal [34]. Testosterone is involved in many aspects of male sexual arousal and function, and suppression of testosterone in men decreases sexual desire and leads to ED and sexual dysfunction [35-37]. In animal models, androgens are essential in the regulation of nitric oxide synthase (NOS), PDE5 activity, and penile muscle cells, supporting the clinical finding that PDE5 inhibitor (PDE5i) efficacy is increased after correction of hypogonadism $[15,38]$. 
Benign prostatic hypertrophy (BPH) and lower urinary tract symptoms (LUTS) have also been linked to ED, and the pathophysiologies of both conditions may be the same [39]. The prevalence of ED is higher in men with LUTS and increases with LUTS severity [2, 40, 41]. Animal models have demonstrated that bladder neck obstruction results in increased cavernosal smooth muscle tone and worse erectile function [42, 43], and investigators have confirmed high expression of PDE5 in the genital tissues, with PDE5i's decreasing genital muscle contraction in a dose-dependent manner [44]. Clinical evidence demonstrates an improvement in International Index of Erectile Function (IIEF) and International Prostate Symptom Score (IPSS) in treated patients, with a small but significant improvement in urinary flow in men taking sildenafil $[45 \bullet, 46]$.

While much work has focused on organic risk factors, ED is also linked to psychological parameters. The risk of LUTS and ED is higher in men with depressive symptoms and has a racial proclivity. The Massachusetts Male Aging Study demonstrated an association between men with ED and depressive symptoms (odds ratio (OR) 1.82) [47]. In a study of 2,173 men completing an interview in the Male Attitudes Regarding Sexual Health Study, men with depressive symptoms had a higher likelihood of LUTS (OR 2.68) and ED (OR 1.73) than men without [48•]. Furthermore, the study found that Hispanic and black men with ED were significantly more likely to report depressive symptoms than white men. Other studies have also demonstrated a strong relationship between ED and depression [49]. When considering psychogenic ED, the link with sexual confidence and performance anxiety should not be overlooked. In 1978, Boyarsky and Boyarsky stressed the need to include psychological principles in the evaluation and treatment of all men with ED [50]. Since then, numerous studies have highlighted the link between ED and sexual confidence/performance anxiety [51, 52], loss of self-esteem, relationship concerns [51], and other psychosocial stresses [53], all of which should be considered in men presenting with ED.

\section{Clinical Evaluation of the Male with Erectile Dysfunction}

The evaluation of the male with ED comprises three categories: (1) history and physical exam, (2) lab testing, and (3) adjunctive testing with imaging and related modalities.

History and Physical Examination-The initial assessment of any sexual problem requires a detailed history and physical exam. Given the risk factors for ED, a broad-based history should be taken in men presenting with ED. A medical history evaluating potential roles of medical conditions in the patient's ED and differentiating between organic and psychological causes of ED is essential. A detailed sexual history aimed at determining the severity, onset, and duration of the ED should also be performed [54•]. A psychosocial assessment is also essential, considering that ED and its treatment are associated with overall quality of life and relationship quality, confidence, self-esteem, and depression [55•].

Objective measures of erectile function should be used in evaluating men with ED, particularly when determining treatment effects. The Sexual Health Inventory for Men (SHIM) is one of the most commonly used validated instruments for evaluation of ED severity, comprised of five questions based on a five-point Likert scale and derived from the gold standard 15-question IIEF, a broader-based instrument with five domains developed for 
use in clinical trials [56-58]. The IIEF has high sensitivity and specificity for detecting treatment effects, but its length makes it inefficient to administer in the office setting, whereas the SHIM is specifically intended as an office screening tool for ED [59, 60]. In scoring the SHIM, lower scores portend worse ED with classification into five severity grades: no ED (SHIM score 22-25), mild (17-21), mild to moderate (12-16), moderate (8$11)$, and severe (1-7).

In light of the link between hypogonadism and ED, clinicians should also consider a validated screening tool for hypogonadism such as the Androgen Deficiency in the Aging Male (ADAM) questionnaire [61]. Comprised of ten yes/no questions, the ADAM questionnaire has a sensitivity of $84-88 \%$, with a specificity of 37-60\%. To potentially improve on this specificity, another option is the quantitative ADAM (qADAM), which utilizes a five-point Likert scale in place of binary yes/no responses [62]. Given the broadbased impact of ED and sexual dysfunction more generally [63], on psychosocial domains of life, evaluation of depressive symptoms and psychosocial status should be included. Several validated instruments exist for this purpose, including the Patient Health Questionnaire (PHQ-9) and the Beck Depression Inventory (BDI), among others.

The physical examination may be illuminating for comorbidities associated with ED, such as Peyronie's disease, and may be instrumental in identifying endocrinopathies via testicular size and consistency as well as other conditions [64] including hypertension [65] and arrhythmias [66]. Physical exam in men with ED is recommended, but not always necessary, according to the International Consultation in Sexual Medicine (ICSM) for the Clinical Evaluation of Men and Women with Sexual Dysfunction [67]. The exam comprises evaluation of the genitalia for lesions, scars, plaques, and meatal position as well as evaluation of the testicles for size and consistency. Examination should also evaluate secondary sex characteristics, peripheral pulses and sensation, abdominal masses, and presence of gynecomastia. Waist and hip circumference may be informative regarding obesity, with the waist-to-hip ratio providing a good metric for evaluation of weight loss and response to hypogonadal therapies [68], and digital rectal examination is recommended in men being considered for hormone replacement.

Understanding the patient's psychosocial circumstances may also be illuminating, as ED may have a significant negative effect on a partner's sexuality and partner's circumstances on the patient [51]. Prior to the introduction of PDE5is, intracavernosal injection (ICI) and vacuum erection devices were the primary nonsurgical interventions in ED treatment. When incorporated into the treatment of ED, both ICI and vacuum erection device (VED) use resulted in improvements in partner's sexual satisfaction [69, 70]. Similarly, in the Female Experience of Men's Attitudes to Life Events and Sexuality (FEMALES) Study, ED had a marked negative effect on female partners, resulting in declines in sexual frequency, desire, arousal, orgasm, and sexual satisfaction, all of which subsequently improved with vardenafil treatment [12]. While significantly less literature exists evaluating the impact of a female partner's status on a patient's ED, several studies have linked vaginal atrophy and vaginismus to sexual dys-function, including ED and premature ejaculation, in male partners $[71,72]$. 
Laboratory Testing-Lab testing in men with ED is focused on the evaluation of ED risk factors and includes tests to assess the hypothalamic-pituitary-gonadal axis, lipid status, and sugar metabolism (Table 3). Lab tests for ED recommended by the ICSM for evaluation of men and women with sexual dysfunction include fasting blood glucose, lipid panel, and gender-specific hormones [67].

Diabetes mellitus occurs in 20-25\% of men with ED, with dyslipidemia occurring in 40-70 $\%[65,73]$. While fasting blood glucose can inform a potential diagnosis of DM, hemoglobin A1C is strongly associated with ED (OR 3.19) and should be considered in lieu of fasting blood glucose or in men with known DM [74]. Assessment of the hypothalamicpituitary-gonadal axis can reveal endocrinopathies that can significantly affect erectile function, including hypogonadism. While pituitary adenomas occur in only $0.4 \%$ and hyperprolactinemia in $0.76 \%$ of men with $\mathrm{ED}$, these conditions can contribute to long-term morbidity if untreated [75]. Given the similarity between symptoms of hypothyroidism and hypogonadism and the contributory effect of hypothyroidism on hypogonadism, thyroid function tests should be considered if the clinical scenario warrants them [76, 77]. In men $\geq 40$ years old, serum PSA evaluation is also indicated, particularly in those who are being considered for testosterone replacement.

Additional Diagnostic Studies in Men with ED-While history, physical examination, and laboratory testing are sufficient to diagnose most physical causes of ED, in complex patients, additional diagnostic studies may identify specific ED etiologies and guide treatment selection. While numerous adjunct tests are available, vascular and psychophysiological evaluations with a strong evidence base are focused on below, given that these may provide significant diagnostic information.

Vascular Evaluation-Specialized vascular evaluation is aimed at diagnosing arterial and venous insufficiency in men with $\mathrm{ED}$. At the most basic level, ICI of one or more vasodilators (evidence level B), combined with genital or visual stimulation, is the simplest way to bypass neurological and hormonal influences and to assess organic erectile function [78]. However, this approach does not provide anatomic data.

Penile duplex ultrasonography (evidence level B), which combines ICI with Doppler ultrasound to evaluate blood flow direction and velocity, is the most common and informative method of assessing for both arterial insufficiency and venoocclusive dysfunction [79]. Men with arteriogenic ED demonstrate a peak systolic velocity (PSV) of $<25 \mathrm{~mL} / \mathrm{s}$, which has $100 \%$ sensitivity and $95 \%$ specificity in men with abnormal pudendal arteriograms. Veno-occlusive dysfunction, in contrast, demonstrates a PSV of $25 \mathrm{~mL} / \mathrm{s}$ or greater, but with a persistent end-diastolic velocity (EDV) of $>5 \mathrm{~mL} / \mathrm{s}$, with a sensitivity of $90 \%$ and specificity of $56 \%$ in the setting of venous leak on penile cavernosometry [80]. The resistive index (RI) (RI=PSV-EDV/PSV) is a measure of vascular resistance based on the Doppler spectrum, with a RI of $\searrow 0.9$ indicative of normal function and a value of $₫ 0.75$ indicative of venous leak [81].

Arteriography (evidence level C) can help define arterial occlusion, although it is better suited for evaluation of anatomy than function and is most useful in young men after 
traumatic arterial disruption or perineal compression injury to plan surgical reconstruction. In the setting of ED, the iliac, internal pudendal, penile, and inferior epigastric arteries are studied.

Dynamic infusion cavernosometry and cavernosography (DICC) (evidence level B) is an alternate method of assessing for venous leak. Cavernosometry involves injection of vasodilator followed by saline infusion with simultaneous cavernous pressure monitoring to assess penile outflow. Venous leak is indicated by an inability to raise intracavernous pressure to mean systolic blood pressure or by a rapid drop in intracavernous pressure after cessation of saline infusion [82]. In contrast, cavernosography involves infusion of radiopaque dye into the corpora after vasodilator injection to visualize the site of leakage. While informative, the utility of DICC is limited by technical factors, restricting its use to young men with a history of trauma or primary ED who are potential revascularization candidates.

Numerous other forms of vascular evaluation in men with ED are available, but the value of these methods is unclear due to an insufficient evidence base or conflicting reports regarding their utility.

Psychophysiological Evaluation-The distinction between psychogenic and organic ED can be made without invasive testing using nocturnal penile tumescence (NPT) evaluation (evidence level B). NPT evaluation determines the number, duration, and rigidity of tumescent episodes during sleep. The RigiScan, introduced in 1985, has facilitated NPT recording, with four to five erectile episodes with a mean duration of 30 min or longer, an increase in penile circumference of $3 \mathrm{~cm}$ at the base and $>2 \mathrm{~cm}$ at the tip, and maximal rigidity of $>70 \%$ at both the penile base and tip considered normal [83]. However, given the overall complexity of the exam, it is not recommended for routine ED evaluation. That being said, the degree of psychogenic involvement can be readily deconvoluted using a thorough sexual history that assesses erection quality on awakening, as well as during masturbation, foreplay, and intercourse [54•]. When variability in erectile function as a function of circumstance is observed, psychogenic ED can be accurately diagnosed. In contrast, men with organic ED are more likely to have consistent difficulties with erection.

\section{Treatment of Erectile Dysfunction}

The treatment of ED comprises psychosexual therapy, lifestyle modifications, and medical and surgical management (Fig. 1) [84, 85]. Medical management is emphasized in this review, with a more limited discussion of surgical interventions. Briefly, psychotherapy is considered as a first-line ED therapy, is both noninvasive and effective, and can be combined with other therapies. In a Cochrane Review of 11 trials of psychotherapy alone or psychotherapy and medication or VED in men with ED, men receiving group psychotherapy alone had less ED at 6-month follow-up when compared to controls, with up to a $95 \%$ success rate, and men concomitantly taking PDE5is were less likely to drop out of therapy [86].

Lifestyle Modification in Men with ED-The third Princeton Consensus Conference in 2010 recommended lifestyle adjustments in men with ED to not only reduce cardiovascular risk but also improve ED symptoms [87••]. A 2011 meta-analysis encompassing 740 
participants demonstrated a SHIM score improvement after $\geq 6$ weeks of lifestyle alteration, even in the absence of statin therapy [88]. While lifestyle alterations benefit ED symptoms, they are most beneficial for primary prevention, with smoking cessation reducing cardiovascular mortality by $36 \%$ [89], physical activity resulting in 30-50\% reductions in DM and CAD incidence [90], and diet reducing death from CAD by up to $36 \%$ [91]. Based on these findings, recommended lifestyle alterations include regular exercise, smoking cessation, dietary intervention with emphasis on the Mediterranean diet, and moderate alcohol consumption.

Hypogonadism and ED-The third Princeton Consensus Conference recommends testosterone supplementation in hypogonadal men with ED [87••], which may ameliorate both ED symptoms as well as cardiovascular risk. Meta-analysis has shown a $57 \%$ overall response rate to testosterone monotherapy in men with ED [92], with an improvement in erectile function in $39 \%$ of men [93•], as well as improvements in sexual performance, desire, and motivation [94]. Serum testosterone levels correlate with sexual symptom onset, with decrements in libido at $\sim 430 \mathrm{ng} / \mathrm{dL}$ and ED at $230-300 \mathrm{ng} / \mathrm{dL}$, with the response to testosterone supplementation only evident starting 4-12 weeks after initiation [95]. Thus, testosterone supplementation should begin prior to treatment with ED-specific medications. In addition, approximately $30 \%$ of men with ED treated with PDE5is do not respond [96]. However, concomitant administration of testosterone or placebo and PDE5is results in a greater improvement in erectile function in men receiving testosterone compared to those receiving placebo [15].

Several studies have explored the role of human chorionic gonadotropin (hCG) and clomiphene citrate on sexual function in hypogonadal men, which is particularly significant in hypogonadal men with ED who wish to achieve fatherhood. The use of hCG to raise testosterone was shown to increase sexual activity in $50 \%$ of men with normal testosterone levels [97]. Using clomiphene citrate to normalize testosterone levels resulted in an improvement in sexual function in $39 \%$ of treated men, with a bias towards younger and healthier individuals [98].

Oral Therapies_-Phosphodiesterase 5 inhibitors are first-line medical therapy for ED [99] and encompass numerous drugs including the first-generation drugs sildenafil (Viagra ${ }^{\circledR}$ ), vardenafil (Levitra $\left.{ }^{\circledR}\right)$, and tadalafil (Cialis $\left.{ }^{\circledR}\right)$ as well as next-generation drugs including avanafil (Stendra $\left.{ }^{\circledR}\right)$, mirodenafil (Mvix $\left.{ }^{\circledR}\right)$, lodenafil (Helleva $\left.{ }^{\circledR}\right)$, and udenafil (Zydena $\left.{ }^{\circledR}\right)$. Udenafil, lodenafil, and mirodenafil are not yet approved for use in the USA but have been approved in other countries. All PDE5is inhibit PDE5, found in high concentrations in the corpora cavernosa, thus blocking $3^{\prime} 5^{\prime}$-cGMP cleavage in the corpora cavernosa and promoting erection. Of note, PDE5is only work with sexual stimulation, as this generates $3^{\prime} 5^{\prime}$-cGMP. Thus, becoming aware of the patient and partner's sexual script will often be useful in determining both choice of medication and dosing strategy used [100].

Sildenafil, tadalafil, and vardenafil are the most popular ED drugs in current use. Sildenafil was the first PDE5i approved for ED treatment, in 1998, and has a time of onset of $30 \mathrm{~min}$, with an 8-h duration of clinical efficacy, pharmacokinetics that are nearly identical to those of vardenafil. Both sildenafil and vardenafil have a delayed onset of action after fatty food 
ingestion. In contrast, tadalafil has a longer time of onset of $2 \mathrm{~h}$, with a 36-h duration of efficacy and with no interaction with food (reviewed in [101]). Next-generation PDE5is are just coming to the market and may have additional benefits when compared with firstgeneration drugs, along with comparable safety profiles in early trials. Avanafil is touted for its rapid onset of $15 \mathrm{~min}$ with a duration of action of $>6 \mathrm{~h}$ [102], whereas lodenafil and mirodenafil are short-acting PDE5is with half-lives of $2.5 \mathrm{~h}$ [103, 104], and udenafil is a long-acting PDE5i with a half-life of 11-13 h [105].

Sildenafil, vardenafil, and tadalafil have all shown efficacy in normal men with use on asneeded as well as long-term bases, with high first-dose response rates. Efficacy has also been demonstrated in subpopulations of men with ED including those with DM, neurological disorders including multiple sclerosis and spinal cord injury, hypertension, CAD, renal insufficiency, status postrenal transplant, and after nerve-sparing radical prostatectomy (reviewed in [106]). Several PDE5is, including tadalafil and sildenafil, may be used daily to either minimize as-needed dosing for sexual activity (tadalafil) in the setting of erectile preservation after surgery (tadalafil, sildenafil) or in the setting of men with concomitant LUTS and ED (tadalafil).

Transurethral Therapies-While limited in its utility, transurethral alprostadil (prostaglandin E1 (PGE1)) is a reasonable first-line or combination ED therapy. First brought to market in 1994 and marketed as Medicated Urethral System for Erection (MUSE®), transurethral alprostadil has shown limited efficacy, with response rates of 27$53 \%$ when compared with 66-96\% for intracavernosally injected alprostadil [107]. In addition, the formulation requires placement into the penile urethra, with penile pain in 25$43 \%$ of patients. However, combination therapy with sildenafil has been shown to salvage the effects of MUSE® in nonresponders [108] and MUSE $®$ is also beneficial in men whose penile nerves have been compromised as it bypasses the need for intact neurological pathways for erection.

Intracavernosal Therapies-Intracavernosal injection therapies constitute a second-line ED treatment and are often used when oral therapies fail. Like MUSE®, injectable therapies bypass the need for intact neurological pathways for erection. Several medications are currently in use and include various combinations of PGE1, phentolamine, papaverine, and vasoactive intestinal peptide (VIP). Many of these medications have been available for two decades or more and constitute some of the most effective ED therapies available.

When used alone, PGE1 results in high rates of erections usable for sexual intercourse, ranging from 91 to $96 \%$ in a European prospective trial [109]. Furthermore, the overall satisfaction rate with ICI using PGE1 was $78.3 \%$ in a study evaluating satisfaction in 596 patients, with $86 \%$ of patients recommending ICI to their friends [110]. The dose range for PGE1 varies from 5 to $40 \mu \mathrm{g}$ and is dependent on the severity and etiology of the ED. Men with poor response are more likely to have arteriogenic ED and hypogonadism, DM, cardiovascular disease, and the metabolic syndrome [111].

A combination of papaverine and phentolamine, marketed as Androskat $₫$ but commonly referred to as bimix, is also available. Bimix is sold as $2-\mathrm{mL}$ vials containing $30 \mathrm{mg}$ 
papaverine and $1 \mathrm{mg}$ phentolamine, with each vial being the equivalent of $10 \mu \mathrm{g}$ of PGE1 [112]. A multicenter study evaluating bimix in 157 men demonstrated an efficacy rate of 94 $\%$ with a side effect incidence of $0.9-2.6 \%$ for prolonged erection, pain, or hematoma [113].

A combination of papaverine $30 \mathrm{mg}$, phentolamine $1 \mathrm{mg}$, and PGE1 $40 \mu \mathrm{g}$, commonly referred to as trimix, is preferred by patients over monotherapy with PGE1, with comparable efficacy in a smaller injected volume (0.1-0.5 vs. $1 \mathrm{~mL}$ for PGE1) [114]. Furthermore, trimix may be superior to PGE1 monotherapy in venous leak ED and results in less penile pain than PGE1 monotherapy. Trimix produces a longer-lasting erection than PGE1 but does increase the risk of priapism [115]. Currently, however, no commercially available version of trimix exists, and the prescription requires reconstitution by pharmacies or patients. A combination of VIP and phentolamine (Invicorp ${ }^{\circledR}$ ) may also be used for ICI and is packaged as VIP/phentolamine $25 \mu \mathrm{g} / 1 \mathrm{mg}$ or $25 \mu \mathrm{g} / 2 \mathrm{mg}$. However, the drug combination is only approved in several countries and not in the USA. A double-blind, placebo-controlled study observed 75-84\% overall response rates in the nonplacebo and placebo phases of the trial [116].

Combination therapy with PDE5i and intracavernosal therapy has shown some success in PGE1 or trimix monotherapy nonresponders, providing an additional medical treatment option in these men. One study of 93 nonresponders demonstrated a satisfactory response to PDE5i monotherapy in only $34 \%$ of patients with $47 \%$ responding to combined PDE5i and trimix and $53 \%$ with persistent nonresponse [117].

Acupuncture and Complementary Medicine-Complementary and alternative medical treatments have been gaining favor in the West. Acupuncture has been used for centuries in a wide variety of conditions, but only recently has it been studied using Western scientific principles. In ED, acupuncture has shown moderate efficacy, with an early study in 1999 of 16 men with ED treated with twice weekly acu-puncture for 8 weeks demonstrating an improvement in erec-tile function in $39 \%$ of men [118]. A more recent systematic review of two uncontrolled clinical trials (UCTs) and two randomized clinical trials (RCTs) [119], however, reported insufficient data to determine acupuncture efficacy in $\mathrm{ED}$, with only one of the four analyzed studies, a RCT, demonstrating a benefit over placebo [120].

Oral complementary medical treatments with potential efficacy in ED treatment include yohimbine, $\mathrm{L}$-arginine, and ginseng. Yohimbine is derived from the bark of the yohimbehe tree and, until PDE5is came onto the market, was the most commonly prescribed ED treatment. In a meta-analysis of clinical trials, yohimbine was found to be superior to placebo [121], but the Clinical Guidelines Panel on Erectile Dysfunction of the American Urological Association concluded that there are insufficient data to recommend yohimbine as a standard ED treatment [122]. L-Arginine is a precursor of NO synthesis, and a recent double-blind, placebo-controlled study of a European commercial L-arginine product demonstrated a significant SHIM score improvement in a cohort of 124 men aged 30-50 with moderate ED [123]. However, the SHIM score improvement was higher than that previously seen with PDE5is, which is in contrast to other studies that have shown response 
rates of $<50 \%$, suggesting the need for additional, larger trials. Ginseng has also shown potential efficacy in ED, though most studies evaluating its effects have been small. In a recent systematic review of the literature incorporating seven RCTs with a total of 349 patients, a risk ratio of 2.40 (95\% CI 1.65-3.50) supported an overall beneficial effect in men with ED. However, the combined sample size and the methodological quality of the studies were overall insufficient to draw rigorous conclusions [124].

While numerous other medications are touted as having efficacy in men with ED, the lack of rigorous evidence base limits their utility and they are not discussed here.

Vacuum Erection Devices in ED-VEDs can be applied in nearly all etiologies of ED, making the VED a first-line ED therapy. Efficacy rates of VED approach those of PDE5is and ICI, but VEDs have low overall acceptance and high long-term discontinuation rates due to the unnatural feeling of the erection and the mechanical procedure required to produce it [125]. Several reports describe improvement in erectile function with the use of VED in combination with PDE5is or ICI in comparison with monotherapy (reviewed in [126]). In addition, VED use is a standard part of postradical prostatectomy (RP) erectile preservation programs when used alone or in combination with PDE5i, ICI, or transurethral therapies and can be used to prevent penile shrinkage after RP and potentially prevent Peyronie's disease as well as after surgery to correct Peyronie's disease to prevent its recurrence [127].

\section{Surgical Therapy in Men with Erectile Dysfunction}

To round out the spectrum of ED treatment, a brief discussion of invasive therapies is essential, with a focus on penile prostheses and penile revascularization procedures.

Penile Prosthesis-Insertion of a penile prosthesis is considered as the third-line therapy for ED, used after patients fail medical therapies. Penile prostheses are available in semirigid and inflatable forms, with the inflatable form being the most popular in the USA. The semirigid prosthesis is easier to implant, however, and may be a better option for men with poor manual dexterity and difficulty using the pump of the inflatable prosthesis. Patient and partner success rates after penile prosthesis implantation are high, reaching 70 and $90 \%$, respectively, with $80 \%$ of patients indicating improvement in their sex lives and $97 \%$ indicating that they would recommend a prosthesis to friends [128]. Penile prostheses require replacement every $8-15$ years, and the most common complication after implantation is infection, occurring in 1-4\% of virgin implants and in fewer antibioticcoated or hydrophilically coated prostheses, but increasing to 3-10\% after revision [129].

Penile Revascularization Surgery-Approaches to penile revascularization include repair of arterial stenosis and penile venous ligation, depending on the ED etiology. Neither of these approaches, however, has a substantial evidence base, with only grade D recommendations offered in the absence of prospective, randomized studies (reviewed in [130]). However, the consensus at this time is that penile revascularization can be offered to nonsmoking, nondiabetic men $<55$ years old with isolated arterial stenoses without 
generalized vascular disease. A consensus for penile venous ligation has not been reached, given the absence of evidentiary support.

The principles guiding penile revascularization include anastomosis of the inferior epigastric artery to the dorsal penile arteries and/or the deep dorsal vein. However, no peer-reviewed study has demonstrated increased corporal inflow after these procedures [131]. Venous ligation spans a spectrum of procedures, ranging from superficial and deep dorsal vein ligation to embolization of penile veins to a combination of approaches, but the emerging consensus is that these procedures fail primarily due to extensive collateral penile venous drainage. In the absence of prospective studies to evaluate the efficacy of penile revascularization procedures, several retrospective studies have evaluated both arterial revascularization and venous ligation procedures, with mixed results. Overall, arterial procedures appear to be more consistently successful than venous ligation procedures [130]. While the current data support intervention in select individuals, a definitive evidence base remains lacking, limiting the ability to identify and appropriately treat patients via revascularization.

Future Therapies-While numerous effective ED treatments exist, additional drug-based, interventional, and genetic therapies are being developed that may improve upon or complement current treatments. Future medical ED therapies include guanylate cyclase inhibitors [132], potassium channel inhibitors [133], melanocortin system activators [134], and Rho kinase inhibitors [135]. Interventional therapies include a zotarolimuseluting stent, which has shown benefit in a trial of three men with pudendal artery stenosis [136]. Gene therapy with the maxi-K potassium channel in a small cohort of 14 men without a control group yielded significant improvements in erec-tile function in men given the highest doses [137]. Additional work evaluating growth factors and cell-based therapies may yield additional fruit to add to the growing cornucopia of ED treatments. Finally, there is accumulating evidence that an integration of counseling with new medical/surgical treatments will improve both efficacy and safety, while simultaneously resulting in greater patient and partner satisfaction [138••, 139].

\section{Conclusions}

Erectile dysfunction significantly limits the quality of life of a growing number of men. Given the rise in conditions predis-posing to ED as well as an aging male population, addressing ED risk factors through lifestyle modification, in conjunction with medical and surgical therapy in appropriate patients, will mitigate the physical and psychological impact of ED. In light of the relationship between ED and several comorbidities, particularly CAD, the role of specialty physicians treating men with ED is expanded to include screening for comorbid conditions that can shorten life with appropriate referral to appropriate treating physicians. Continued research into the molecular mechanisms of ED and development of improved medications to address ED and its risk factors will further expand the significant armamentarium of treatments currently available, improving not only the quality of life of affected men but also their life span. 


\section{References}

Papers of particular interest, published recently, have been highlighted as:

- Of importance

•• Of major importance

1. Hyde Z, Flicker L, Hankey GJ, Almeida OP, McCaul KA, Chubb SA, et al. Prevalence of sexual activity and associated factors in men aged 75 to 95 years: a cohort study. Ann Intern Med. 2010; 153(11):693-702. [PubMed: 21135292]

2. Braun M, Wassmer G, Klotz T, Reifenrath B, Mathers M, Engelmann U. Epidemiology of erectile dysfunction: results of the 'Cologne Male Survey'. Int J Impot Res. 2000; 12(6):305-11. [PubMed: 11416833]

3. Lindau ST, Schumm LP, Laumann EO, Levinson W, O'Muircheartaigh CA, Waite LJ. A study of sexuality and health among older adults in the United States. N Engl J Med. 2007; 357(8):762-74. [PubMed: 17715410]

4. Beckman N, Waern M, Ostling S, Sundh V, Skoog I. Determinants of Sexual Activity in Four Birth Cohorts of Swedish 70-year-olds Examined 1971-2001. J Sex Med. 2014; 11:401-10. [PubMed: 24251617]

5. Perelman MA. Sex coaching for physicians: combination treatment for patient and partner. Int $\mathbf{J}$ Impot Res. 2003; 15(Suppl 5):S67-74. [PubMed: 14551580]

6. Mykletun A, Dahl AA, O'Leary MP, Fossa SD. Assessment of male sexual function by the Brief Sexual Function Inventory. BJU Int. 2006; 97(2):316-23. [PubMed: 16430637]

7. O'Leary MP, Rhodes T, Girman CJ, Jacobson DJ, Roberts RO, Lieber MM, et al. Distribution of the Brief Male Sexual Inventory in community men. Int J Impot Res. 2003; 15(3):185-91. [PubMed: 12904804]

8. Panser LA, Rhodes T, Girman CJ, Guess HA, Chute CG, Oesterling JE, et al. Sexual function of men ages 40 to 79 years: the Olmsted County study of urinary symptoms and health status among men. J Am Geriatr Soc. 1995; 43(10):1107-11. [PubMed: 7560700]

9. Muller MJ, Ruof J, Graf-Morgenstern M, Porst H, Benkert O. Quality of partnership in patients with erectile dysfunction after sildenafil treatment. Pharmacopsychiatry. 2001; 34(3):91-5. [PubMed: 11434405]

10. Litwin MS, Nied RJ, Dhanani N. Health-related quality of life in men with erectile dysfunction. J Gen Intern Med. 1998; 13(3):159-66. [PubMed: 9541372]

11. Shabsigh R, Klein LT, Seidman S, Kaplan SA, Lehrhoff BJ, Ritter JS. Increased incidence of depressive symptoms in men with erectile dysfunction. Urology. 1998; 52(5):848-52. [PubMed: 9801112]

12. Fisher WA, Rosen RC, Eardley I, Sand M, Goldstein I. Sexual experience of female partners of men with erectile dysfunction: the female experience of men's attitudes to life events and sexuality (FEMALES) study. J Sex Med. 2005; 2(5):675-84. [PubMed: 16422826]

13. Oberg K, Sjogren Fugl-Meyer K. On Swedish women's distressing sexual dysfunctions: some concomitant conditions and life satisfaction. J Sex Med. 2005; 2(2):169-80. [PubMed: 16422883]

14. Tsertsvadze, A.; Yazdi, F.; Fink, HA., et al. Diagnosis and treatment of erectile dysfunction. Vol. 171. Agency for Healthcare Research and Quality (US); Rockville: 2009.

15. Shabsigh R, Kaufman JM, Steidle C, Padma-Nathan H. Randomized study of testosterone gel as adjunctive therapy to sildenafil in hypogonadal men with erectile dysfunction who do not respond to sildenafil alone. J Urol. 2004; 172(2):658-63. [PubMed: 15247755]

16. Lin CS, Lin G, Lue TF. Cyclic nucleotide signaling in cavernous smooth muscle. J Sex Med. 2005; 2(4):478-91. [PubMed: 16422842]

17. Lue TF. Erectile dysfunction. N Engl J Med. 2000; 342(24):1802-13. [PubMed: 10853004]

18. Jin L, Burnett AL. RhoA/Rho-kinase in erectile tissue: mechanisms of disease and therapeutic insights. Clin Sci. 2006; 110(2):153-65. [PubMed: 16411892] 
19. NIH Consensus Conference. Impotence. NIH Consensus Development Panel on Impotence. JAMA. 1993; 270(1):83-90. No Authors. [PubMed: 8510302]

20. Selvin E, Burnett AL, Platz EA. Prevalence and risk factors for erectile dysfunction in the US. Am J Med. 2007; 120(2):151-7. [PubMed: 17275456]

21. Guo W, Liao C, Zou Y, Li F, Li T, Zhou Q, et al. Erectile dysfunction and risk of clinical cardiovascular events: a meta-analysis of seven cohort studies. J Sex Med. 2010; 7(8):2805-16. [PubMed: 20367771]

22. Thompson IM, Tangen CM, Goodman PJ, Probstfield JL, Moinpour CM, Coltman CA. Erectile dysfunction and subsequent cardiovascular disease. JAMA. 2005; 294(23):2996-3002. [PubMed: 16414947]

23. Jackson G, Boon N, Eardley I, Kirby M, Dean J, Hackett G, et al. Erectile dysfunction and coronary artery disease prediction: evidence-based guidance and consensus. Int J Clin Pract. 2010; 64(7):848-57. [PubMed: 20584218]

24. Montorsi P, Ravagnani PM, Galli S, Rotatori F, Veglia F, Briganti A, et al. Association between erectile dysfunction and coronary artery disease. Role of coronary clinical presentation and extent of coronary vessels involvement: the COBRA trial. Eur Heart J. 2006; 27(22):2632-9. [PubMed: 16854949]

25. Polonsky TS, Taillon LA, Sheth H, Min JK, Archer SL, Ward RP. The association between erectile dysfunction and peripheral arterial disease as determined by screening ankle-brachial index testing. Atherosclerosis. 2009; 207(2):440-4. [PubMed: 19501825]

26. Ponholzer A, Temml C, Obermayr R, Wehrberger C, Madersbacher S. Is erectile dysfunction an indicator for increased risk of coronary heart disease and stroke? Eur Urol. 2005; 48(3):512-8. Discussion 517-518. [PubMed: 15998563]

27. Blanker MH, Bohnen AM, Groeneveld FP, Bernsen RM, Prins A, Thomas S, et al. Correlates for erectile and ejaculatory dysfunction in older Dutch men: a community-based study. J Am Geriatr Soc. 2001; 49(4):436-42. [PubMed: 11347788]

28. Bacon CG, Mittleman MA, Kawachi I, Giovannucci E, Glasser DB, Rimm EB. Sexual function in men older than 50 years of age: results from the health professionals follow-up study. Ann Intern Med. 2003; 139(3):161-8. [PubMed: 12899583]

29. Feldman HA, Johannes CB, Derby CA, Kleinman KP, Mohr BA, Araujo AB, et al. Erectile dysfunction and coronary risk factors: prospective results from the Massachusetts male aging study. Prev Med. 2000; 30(4):328-38. [PubMed: 10731462]

30. Esposito K, Giugliano D. Obesity, the metabolic syndrome, and sexual dysfunction. Int J Impot Res. 2005; 17(5):391-8. [PubMed: 15902279]

31. Esposito K, Giugliano F, Di Palo C, Giugliano G, Marfella R, D'Andrea F, et al. Effect of lifestyle changes on erectile dysfunction in obese men: a randomized controlled trial. JAMA. 2004; 291(24):2978-84. [PubMed: 15213209]

32. Isidori AM, Buvat J, Corona G, Goldstein I, Jannini EA, Lenzi A, et al. A critical analysis of the role of testosterone in erectile function: from pathophysiology to treatment-a systematic review. Eur Urol. 2014; 65:99-112. [PubMed: 24050791]

33. Chughtai B, Lee RK, Te AE, Kaplan SA. Metabolic syndrome and sexual dysfunction. Curr Opin Urol. 2011; 21(6):514-8. [PubMed: 21897258]

34. Gore J, Rajfer J. The role of serum testosterone testing: routine hormone analysis is an essential part of the initial screening of men with erectile dysfunction. Rev Urol. 2004; 6(4):207-10. [PubMed: 16985604]

35. Shabsigh R. Testosterone therapy in erectile dysfunction and hypogonadism. J Sex Med. 2005; 2(6):785-92. [PubMed: 16422803]

36. Blute M, Hakimian P, Kashanian J, Shteynshluyger A, Lee M, Shabsigh R. Erectile dysfunction and testosterone deficiency. Front Horm Res. 2009; 37:108-22. [PubMed: 19011292]

37. Buvat J, Maggi M, Gooren L, Guay AT, Kaufman J, Morgentaler A, et al. Endocrine aspects of male sexual dysfunctions. J Sex Med. 2010; 7(4 Pt 2):1627-56. [PubMed: 20388162]

38. Shabsigh R, Rajfer J, Aversa A, Traish AM, Yassin A, Kalinchenko SY, et al. The evolving role of testosterone in the treatment of erectile dysfunction. Int J Clin Pract. 2006; 60(9):1087-92. [PubMed: 16939550] 
39. Glina S, Glina FP. Pathogenic mechanisms linking benign prostatic hyperplasia, lower urinary tract symptoms and erectile dys-function. Ther Adv Urol. 2013; 5(4):211-8. [PubMed: 23904860]

40. Nicolosi A, Moreira ED Jr, Shirai M, Bin Mohd Tambi MI, Glasser DB. Epidemiology of erectile dysfunction in four countries: cross-national study of the prevalence and correlates of erectile dysfunction. Urology. 2003; 61(1):201-6. [PubMed: 12559296]

41. Laumann EO, Paik A, Rosen RC. Sexual dysfunction in the United States: prevalence and predictors. JAMA. 1999; 281(6):537-44. [PubMed: 10022110]

42. Chang S, Hypolite JA, Zderic SA, Wein AJ, Chacko S, Disanto ME. Increased corpus cavernosum smooth muscle tone associated with partial bladder outlet obstruction is mediated via Rho-kinase. Am J Physiol Regul, Integr Comp Physiol. 2005; 289(4):R1124-30. [PubMed: 15961528]

43. Kobayashi K, Kato R, Hisasue S, Yamashita S, Tanaka T, Masumori N, et al. Animal model for the study of the relationship between lower urinary tract symptoms/bladder outlet obstruction and erectile dysfunction. Int J Urol. 2011; 18(10):710-5. [PubMed: 21793940]

44. Tinel H, Stelte-Ludwig B, Hutter J, Sandner P. Pre-clinical evidence for the use of phosphodiesterase-5 inhibitors for treating benign prostatic hyperplasia and lower urinary tract symptoms. BJU Int. 2006; 98(6):1259-63. [PubMed: 16956354]

45•. Gacci M, Corona G, Salvi M, Vignozzi L, McVary KT, Kaplan SA, et al. A systematic review and meta-analysis on the use of phosphodiesterase 5 inhibitors alone or in combination with alpha-blockers for lower urinary tract symptoms due to benign prostatic hyperplasia. Eur Urol. 2012; 61(5):994-1003. [PubMed: 22405510] [Significant due to its overall review of the literature evaluating PDE5i use in combination with alpha blockers for BPH/LUTS supporting the conclusion that PDE5i therapy can significantly improve LUTS and erectile function in men with BPH.]

46. Ozturk MI, Koca O, Sertkaya Z, Keles MO, Kaya C, Karaman MI. Acute effects of sildenafil on uroflowmetric parameters in erectile dysfunction patients with and without lower urinary tract symptoms. J Androl. 2012; 33(6):1165-8. [PubMed: 22492839]

47. Araujo AB, Durante R, Feldman HA, Goldstein I, McKinlay JB. The relationship between depressive symptoms and male erectile dysfunction: cross-sectional results from the Massachusetts Male Aging Study. Psychosom Med. 1998; 60(4):458-65. [PubMed: 9710291]

48. Laumann EO, Kang JH, Glasser DB, Rosen RC, Carson CC. Lower urinary tract symptoms are associated with depressive symptoms in white, black and Hispanic men in the United States. J Urol. 2008; 180(1):233-40. [PubMed: 18499181] [An important study linking lower urinary tract symptoms, including erectile dysfunction, to depression, with differentiation by race.]

49. Perelman MA. Erectile dysfunction and depression: screening and treatment. Urol Clin N Am. 2011; 38(2):125-39.

50. Boyarsky RE, Boyarsky S. Urological and behavioral approach to the treatment of secondary impotence. J Urol. 1978; 119(2):229-30. [PubMed: 633482]

51. Althof SE, Wieder M. Psychotherapy for erectile dysfunction: now more relevant than ever. Endocrine. 2004; 23(2-3):131-4. [PubMed: 15146091]

52. Morse WI, Morse JM. Erectile impotence precipitated by organic factors and perpetuated by performance anxiety. Can Med Assoc J. 1982; 127(7):599-601. [PubMed: 7127227]

53. Rosen RC. Psychogenic erectile dysfunction. Classification and management. Urol Clin N Am. 2001; 28(2):269-78.

54-. Althof SE, Rosen RC, Perelman MA, Rubio-Aurioles E. Standard operating procedures for taking a sexual history. J Sex Med. 2013; 10(1):26-35. [PubMed: 22970717] [An excellent primer on obtaining a sexual history.]

55•. McCabe MP, Althof SE. A systematic review of the psychosocial outcomes associated with erectile dysfunction: does the impact of erectile dysfunction extend beyond a man's inability to have sex? The Journal of Sexual Medicine. 2013 [Significant work demonstrating the impact of ED beyond the ability of a man to have sex and extending this impact to overall quality of life.]

56. Rosen RC, Cappelleri JC, Smith MD, Lipsky J, Pena BM. Development and evaluation of an abridged, 5-item version of the International Index of Erectile Function (IIEF-5) as a diagnostic tool for erectile dysfunction. Int J Impot Res. 1999; 11(6):319-26. [PubMed: 10637462] 
57. Rosen RC, Riley A, Wagner G, Osterloh IH, Kirkpatrick J, Mishra A. The international index of erectile function (IIEF): a multidimensional scale for assessment of erectile dysfunction. Urology. 1997; 49(6):822-30. [PubMed: 9187685]

58. Rosen RC, Cappelleri JC, Gendrano N 3rd. The International Index of Erectile Function (IIEF): a state-of-the-science review. Int J Impot Res. 2002; 14(4):226-44. [PubMed: 12152111]

59. Cappelleri JC, Rosen RC. The Sexual Health Inventory for Men (SHIM): a 5-year review of research and clinical experience. Int J Impot Res. 2005; 17(4):307-19. [PubMed: 15875061]

60. Perelman MA. The impact of relationship variables on the etiology, diagnosis and treatment of erectile dysfunction. Adv Primary Care Med: Clin Updat. 2007; 3:3-6.

61. Morley JE, Charlton E, Patrick P, Kaiser FE, Cadeau P, McCready D, et al. Validation of a screening questionnaire for androgen deficiency in aging males. Metab Clin Exp. 2000; 49(9): 1239-42. [PubMed: 11016912]

62. Mohamed O, Freundlich RE, Dakik HK, Grober ED, Najari B, Lipshultz LI, et al. The quantitative ADAM questionnaire: a new tool in quantifying the severity of hypogonadism. Int J Impot Res. 2010; 22(1):20-4. [PubMed: 19657348]

63. Pastuszak AW, Badhiwala N, Lipshultz LI, Khera M. Depression is correlated with the psychological and physical aspects of sexual dysfunction in men. Int J Impot Res. 2013; 25(5): 194-9. [PubMed: 23466661]

64. Hatzichristou D, Hatzimouratidis K, Bekas M, Apostolidis A, Tzortzis V, Yannakoyorgos K. Diagnostic steps in the evaluation of patients with erectile dysfunction. J Urol. 2002; 168(2):61520. [PubMed: 12131320]

65. Seftel AD, Sun P, Swindle R. The prevalence of hypertension, hyperlipidemia, diabetes mellitus and depression in men with erectile dysfunction. J Urol. 2004; 171(6 Pt 1):2341-5. [PubMed: 15126817]

66. Ghanem HM, Salonia A, Martin-Morales A. SOP: physical examination and laboratory testing for men with erectile dysfunction. J Sex Med. 2013; 10(1):108-10. [PubMed: 22524416]

67. Hatzichristou D, Rosen RC, Derogatis LR, Low WY, Meuleman EJ, Sadovsky R, et al. Recommendations for the clinical evaluation of men and women with sexual dysfunction. J Sex Med. 2010; 7(1 Pt 2):337-48. [PubMed: 20092443]

68. Kalinchenko SY, Tishova YA, Mskhalaya GJ, Gooren LJ, Giltay EJ, Saad F. Effects of testosterone supplementation on markers of the metabolic syndrome and inflammation in hypogonadal men with the metabolic syndrome: the double-blinded placebo-controlled Moscow study. Clin Endocrinol. 2010; 73(5):602-12.

69. Althof SE, Turner LA, Levine SB, Risen C, Kursh ED, Bodner D, et al. Intracavernosal injection in the treatment of impotence: a prospective study of sexual, psychological, and marital functioning. J Sex Marital Ther. 1987; 13(3):155-67. [PubMed: 2444712]

70. Turner LA, Althof SE, Levine SB, Tobias TR, Kursh ED, Bodner D, et al. Treating erectile dysfunction with external vacuum devices: impact upon sexual, psychological and marital functioning. J Urol. 1990; 144(1):79-82. [PubMed: 2359184]

71. Nappi RE, Kingsberg S, Maamari R, Simon J. The CLOSER (CLarifying Vaginal Atrophy's Impact On SEx and Relationships) survey: implications of vaginal discomfort in post-menopausal women and in male partners. J Sex Med. 2013; 10(9):2232-41. [PubMed: 23809691]

72. Dogan S, Dogan M. The frequency of sexual dysfunctions in male partners of women with vaginismus in a Turkish sample. Int J Impot Res. 2008; 20(2):218-21. [PubMed: 17882229]

73. Roumeguere T, Wespes E, Carpentier Y, Hoffmann P, Schulman CC. Erectile dysfunction is associated with a high prevalence of hyperlipidemia and coronary heart disease risk. Eur Urol. 2003; 44(3):355-9. [PubMed: 12932936]

74. Weinberg AE, Eisenberg M, Patel CJ, Chertow GM, Leppert JT. Diabetes severity, metabolic syndrome, and the risk of erectile dysfunction. J Sex Med. 2013; 10:3102-9. [PubMed: 24010555]

75. Buvat J. Hyperprolactinemia and sexual function in men: a short review. Int J Impot Res. 2003; 15(5):373-7. [PubMed: 14562140]

76. Donnelly P, White C. Testicular dysfunction in men with primary hypothyroidism; reversal of hypogonadotrophic hypogonadism with replacement thyroxine. Clin Endocrinol. 2000; 52(2):197201. 
77. Kumar A, Chaturvedi PK, Mohanty BP. Hypoandrogenaemia is associated with subclinical hypothyroidism in men. Int J Androl. 2007; 30(1):14-20. [PubMed: 16879621]

78. Donatucci CF, Lue TF. The combined intracavernous injection and stimulation test: diagnostic accuracy. J Urol. 1992; 148(1):61-2. [PubMed: 1613883]

79. Broderick GA, Arger P. Duplex Doppler ultrasonography: noninvasive assessment of penile anatomy and function. Semin Roentgenol. 1993; 28(1):43-56. [PubMed: 8465207]

80. Lewis RW, King BF. Dynamic color Doppler sonography in the evaluation of penile erectile disorders. Int J Impot Res. 1994; 6:A30. Abstract.

81. Naroda T, Yamanaka M, Matsushita K, et al. Evaluation of resistive index of the cavernous artery with color Doppler ultrasonography for venogenic impotence. Int J Impot Res. 1994; 6:D62.

82. Rudnick J, Bodecker R, Weidner W. Significance of the intracavernosal pharmacological injection test, pharmacocavernosography, artificial erection and cavernosometry in the diagnosis of venous leakage. Urol Int. 1991; 46(4):338-43. [PubMed: 1926650]

83. Cilurzo P, Canale D, Turchi P, Giorgi PM, Menchini Fabris GF. The Rigiscan system in the diagnosis of male sexual impotence. Archivio italiano di urologia, nefrologia, andrologia : organo ufficiale dell' Associazione per la ricerca in urologia = Urol, Nephrological, and Andrological Sci. 1992; 64(2):81-5.

84. Perelman, MA. The history of sexual medicine.. In: Diamond, L.; Tolman, D., editors. APA handbook of sexuality and psychology. American Psychological Association; Washington, D.C.: 2014.

85. Perelman MA. The sexual tipping point: a mind/body model for sexual medicine. J Sex Med. 2009; 6(3):629-32. [PubMed: 19210711]

86. Melnik T, Soares BG, Nasselo AG. Psychosocial interventions for erectile dysfunction. Cochrane Database System Rev. 2007; (3):CD004825. [PubMed: 17636774]

87••. Nehra A, Jackson G, Miner M, Billups KL, Burnett AL, Buvat J, et al. The Princeton III Consensus recommendations for the management of erectile dysfunction and cardiovascular disease. Mayo Clin Proc Mayo Clin. 2012; 87(8):766-78. [A critically important work evaluating the link between sexual function and cardiovascular risk in men and recommending cardiovascular evaluation in men with ED. This work supports the link between ED and general health, and the impact that both specialty and general physicians can have on the overall health of their patients.]

88. Gupta BP, Murad MH, Clifton MM, Prokop L, Nehra A, Kopecky SL. The effect of lifestyle modification and cardiovascular risk factor reduction on erectile dysfunction: a systematic review and meta-analysis. Arch Int Med. 2011; 17(20):1797-803. [PubMed: 21911624] [A very important work synthesizing the data on lifestyle modification and its impact on ED and demonstrating that lifestyle modification, even in the absence of medical therapy, can significantly improve ED and further linking ED to CAD and its associated risk factors.]

89. Critchley JA, Capewell S. Mortality risk reduction associated with smoking cessation in patients with coronary heart disease: a systematic review. JAMA. 2003; 290(1):86-97. [PubMed: 12837716]

90. Bassuk SS, Manson JE. Epidemiological evidence for the role of physical activity in reducing risk of type 2 diabetes and cardiovascular disease. J Appl Physiol. 2005; 99(3):1193-204. [PubMed: 16103522]

91. Mozaffarian D, Wilson PW, Kannel WB. Beyond established and novel risk factors: lifestyle risk factors for cardiovascular disease. Circulation. 2008; 117(23):3031-8. [PubMed: 18541753]

92. Jain P, Rademaker AW, McVary KT. Testosterone supplementation for erectile dysfunction: results of a meta-analysis. J Urol. 2000; 164(2):371-5. [PubMed: 10893588]

93•. Isidori AM, Buvat J, Corona G, Goldstein I, Jannini EA, Lenzi A, et al. A critical analysis of the role of testosterone in erectile function: from pathophysiology to treatment-a systematic review. Eur Urol. 2014; 65(1):99-112. [PubMed: 24050791] [This work evaluated the impact of testosterone on erectile function using the existing literature, strongly supporting the biochemical and clinical roles of testosterone in hypogonadal men with ED and developing a pathophysiology-based treatment algorithm for hypogonadal men with ED.] 
94. Wang C, Swerdloff RS, Iranmanesh A, Dobs A, Snyder PJ, Cunningham G, et al. Transdermal testosterone gel improves sexual function, mood, muscle strength, and body composition parameters in hypogonadal men. J Clin Endocrinol Metab. 2000; 85(8):2839-53. [PubMed: 10946892]

95. Porst H, Burnett A, Brock G, Ghanem H, Giuliano F, Glina S, et al. SOP conservative (medical and mechanical) treatment of erectile dysfunction. J Sex Med. 2013; 10(1):130-71. [PubMed: 23343170]

96. Tsertsvadze A, Fink HA, Yazdi F, MacDonald R, Bella AJ, Ansari MT, et al. Oral phosphodiesterase-5 inhibitors and hormonal treatments for erectile dysfunction: a systematic review and meta-analysis. Ann Intern Med. 2009; 151(9):650-61. [PubMed: 19884626]

97. Buvat J, Lemaire A, Buvat-Herbaut M. Human chorionic gonadotropin treatment of nonorganic erectile failure and lack of sexual desire: a double-blind study. Urology. 1987; 30(3):216-9. [PubMed: 3307093]

98. Guay AT, Bansal S, Heatley GJ. Effect of raising endogenous testosterone levels in impotent men with secondary hypogonadism: double blind placebo-controlled trial with clomiphene citrate. J Clin Endocrinol Metab. 1995; 80(12):3546-52. [PubMed: 8530597]

99. Hatzimouratidis K, Amar E, Eardley I, Giuliano F, Hatzichristou D, Montorsi F, et al. Guidelines on male sexual dysfunction: erectile dysfunction and premature ejaculation. Eur Urol. 2010; 57(5): 804-14. [PubMed: 20189712]

100. Dunn ME, Althof SE, Perelman MA. Phosphodiesterase type 5 inhibitors' extended duration of response as a variable in the treatment of erectile dysfunction. Int J Impot Res. 2007; 19(2):11923. [PubMed: 16738695]

101. Wespes E, Amar E, Hatzichristou D, Hatzimouratidis K, Montorsi F, Pryor J, et al. EAU guidelines on erectile dysfunction: an update. Eur Urol. 2006; 49(5):806-15. [PubMed: 16530932]

102. Goldstein I, McCullough AR, Jones LA, Hellstrom WJ, Bowden CH, Didonato K, et al. A randomized, double-blind, placebo-controlled evaluation of the safety and efficacy of avanafil in subjects with erectile dysfunction. J Sex Med. 2012; 9(4):1122-33. [PubMed: 22248153]

103. Glina S, Fonseca GN, Bertero EB, Damiao R, Rocha LC, Jardim CR, et al. Efficacy and tolerability of lodenafil carbonate for oral therapy of erectile dysfunction: a phase III clinical trial. J Sex Med. 2010; 7(5):1928-36. [PubMed: 20214718]

104. Paick JS, Ahn TY, Choi HK, Chung WS, Kim JJ, Kim SC, et al. Efficacy and safety of mirodenafil, a new oral phosphodiesterase type 5 inhibitor, for treatment of erectile dysfunction. J Sex Med. 2008; 5(11):2672-80. [PubMed: 18638004]

105. Kim BH, Lim HS, Chung JY, Kim JR, Lim KS, Sohn DR, et al. Safety, tolerability and pharmacokinetics of udenafil, a novel PDE-5 inhibitor, in healthy young Korean subjects. $\mathrm{Br} \mathrm{J}$ Clin Pharmacol. 2008; 65(6):848-54. [PubMed: 18318773]

106. Wylie K. Erectile dysfunction. Adv Psychosom Med. 2008; 29:33-49. [PubMed: 18391556]

107. Porst, H.; Adaikan, G. Self-injection, transurethral and topical therapy in erectile dysfunction.. In: Porst, H.; Buvat, J., editors. Standard practice in sexual medicine. Blackwell Publishing; Malden: 2006. p. 94-108.

108. Mydlo JH, Volpe MA, Macchia RJ. Initial results utilizing combination therapy for patients with a suboptimal response to either alprostadil or sildenafil monotherapy. Eur Urol. 2000; 38(1):304. [PubMed: 10859438]

109. Porst H, Buvat J, Meuleman E, Michal V, Wagner G. Intracavernous alprostadil alfadex-an effective and well tolerated treatment for erectile dysfunction. Results a long-term European study. Int J Impot Res. 1998; 10(4):225-31. [PubMed: 9884918]

110. Alexandre B, Lemaire A, Desvaux P, Amar E. Intracavernous injections of prostaglandin E1 for erectile dysfunction: patient satisfaction and quality of sex life on long-term treatment. J Sex Med. 2007; 4(2):426-31. [PubMed: 17367438]

111. Rastrelli G, Corona G, Monami M, Melani C, Balzi D, Sforza A, et al. Poor response to alprostadil ICI test is associated with arteriogenic erectile dysfunction and higher risk of major adverse cardiovascular events. J Sex Med. 2011; 8(12):3433-45. [PubMed: 21995713] 
112. Porst $\mathrm{H}$. The rationale for prostaglandin $\mathrm{E} 1$ in erectile failure: a survey of worldwide experience. J Urol. 1996; 155(3):802-15. [PubMed: 8583582]

113. Thon WF, Hartmann U. [Effectiveness and safety of cavernous body auto-injection therapy with papaverine/phentolamine. Study group]. Der Urologe Ausg A. 1993; 32(6):466-9. [PubMed: 8284856]

114. Kulaksizoglu H, Hakim LS, Nehra A, Goldstein I. Comparison of alprostadil sterile powder (Caverject ${ }^{\circledR}$ ) with trimix. Nomogram and patient satisfaction. J Urol. 1997; 157(Suppl 4):180.

115. Seyam R, Mohamed K, Akhras AA, Rashwan H. A prospective randomized study to optimize the dosage of trimix ingredients and compare its efficacy and safety with prostaglandin E1. Int $\mathrm{J}$ Impot Res. 2005; 17(4):346-53. [PubMed: 15772683]

116. Sandhu D, Curless E, Dean J, Hackett G, Liu S, Savage D, et al. A double blind, placebo controlled study of intracavernosal vasoactive intestinal polypeptide and phenotolamine mesylate in a novel auto-injector for the treatment of non-psychogenic erectile dys-function. Int J Impot Res. 1999; 11(2):91-7. [PubMed: 10356669]

117. McMahon CG, Samali R, Johnson H. Treatment of intracorporeal injection nonresponse with sildenafil alone or in combination with triple agent intracorporeal injection therapy. J Urol. 1999; 162(6):1992-7. Discussion 1997-1998. [PubMed: 10569554]

118. Kho HG, Sweep CG, Chen X, Rabsztyn PR, Meuleman EJ. The use of acupuncture in the treatment of erectile dysfunction. Int J Impot Res. 1999; 11(1):41-6. [PubMed: 10098953]

119. Lee MS, Shin BC, Ernst E. Acupuncture for treating erectile dysfunction: a systematic review. BJU Int. 2009; 104(3):366-70. [PubMed: 19239450]

120. Engelhardt PF, Daha LK, Zils T, Simak R, Konig K, Pfluger H. Acupuncture in the treatment of psychogenic erectile dysfunction: first results of a prospective randomized placebo-controlled study. Int J Impot Res. 2003; 15(5):343-6. [PubMed: 14562135]

121. Ernst E, Pittler MH. Yohimbine for erectile dysfunction: a systematic review and meta-analysis of randomized clinical trials. J Urol. 1998; 159(2):433-6. [PubMed: 9649257]

122. Montague DK, Jarow JP, Broderick GA, Dmochowski RR, Heaton JP, Lue TF, et al. Chapter 1: The management of erectile dysfunction: an AUA update. J Urol. 2005; 174(1):230-9. [PubMed: 15947645]

123. Ledda A, Belcaro G, Cesarone MR, Dugall M, Schonlau F. Investigation of a complex plant extract for mild to moderate erectile dysfunction in a randomized, double-blind, placebocontrolled, parallel-arm study. BJU Int. 2010; 106(7):1030-3. [PubMed: 20184576]

124. Jang DJ, Lee MS, Shin BC, Lee YC, Ernst E. Red ginseng for treating erectile dysfunction: a systematic review. Br J Clin Pharmacol. 2008; 66(4):444-50. [PubMed: 18754850]

125. Meuleman EJ. Experiences with a vacuum apparatus in the treatment of erection disorders. Nederlands Tijdschrift voor Geneeskunde. 1993; 137(8):412-6. [PubMed: 8446200]

126. Brison D, Seftel A, Sadeghi-Nejad H. The resurgence of the vacuum erection device (VED) for treatment of erectile dysfunction. J Sex Med. 2013; 10(4):1124-35. [PubMed: 23347150]

127. Pahlajani G, Raina R, Jones S, Ali M, Zippe C. Vacuum erection devices revisited: its emerging role in the treatment of erectile dysfunction and early penile rehabilitation following prostate cancer therapy. J Sex Med. 2012; 9(4):1182-9. [PubMed: 21054791]

128. Bettocchi C, Palumbo F, Spilotros M, Lucarelli G, Palazzo S, Battaglia M, et al. Patient and partner satisfaction after AMS inflatable penile prosthesis implant. J S Med. 2010; 7(1 Pt 1):3049.

129. Wilson SK, Zumbe J, Henry GD, Salem EA, Delk JR, Cleves MA. Infection reduction using antibiotic-coated inflatable penile pros-thesis. Urology. 2007; 70(2):337-40. [PubMed: 17826502]

130. Sohn M, Hatzinger M, Goldstein I, Krishnamurti S. Standard operating procedures for vascular surgery in erectile dysfunction: revascularization and venous procedures. J Sex Med. 2013; 10(1):172-9. [PubMed: 23171072]

131. Sohn, M.; Martin-Morales, A. Surgical treatment of erectile dys-function.. In: Porst, JB.; Buvat, J., editors. Standard practice in sexual medicine. Wiley; Hoboken: 2006. p. 126-48. 
132. Brioni JD, Nakane M, Hsieh GC, Moreland RB, Kolasa T, Sullivan JP. Activators of soluble guanylate cyclase for the treatment of male erectile dysfunction. Int J Impot Res. 2002; 14(1):814. [PubMed: 11896472]

133. Venkateswarlu K, Giraldi A, Zhao W, Wang HZ, Melman A, Spektor M, et al. Potassium channels and human corporeal smooth muscle cell tone: diabetes and relaxation of human corpus cavernosum smooth muscle by adenosine triphosphate sensitive potassium channel openers. J Urol. 2002; 168(1):355-61. [PubMed: 12050569]

134. Martin WJ, McGowan E, Cashen DE, Gantert LT, Drisko JE, Hom GJ, et al. Activation of melanocortin MC(4) receptors increases erectile activity in rats ex copula. Eur J Pharmacol. 2002; 454(1):71-9. [PubMed: 12409007]

135. Chitaley K, Wingard CJ, Clinton Webb R, Branam H, Stopper VS, Lewis RW, et al. Antagonism of Rho-kinase stimulates rat penile erection via a nitric oxide-independent pathway. Nat Med. 2001; 7(1):119-22. [PubMed: 11135626]

136. Babaev A, Jhaveri RR. Angiography and endovascular revascularization of pudendal artery atherosclerotic disease in patients with medically refractory erectile dysfunction. J Invasive Card. 2012; 24(5):236-40.

137. Melman A, Bar-Chama N, McCullough A, Davies K, Christ G. hMaxi-K gene transfer in males with erectile dysfunction: results of the first human trial. Hum Gene Ther. 2006; 17(12):1165-76. [PubMed: 17134370]

138••. Perelman MA. Psychosocial evaluation and combination treatment of men with erectile dysfunction. Urol Clin North Am. 2005; 32(4):431-445. vi. [PubMed: 16291035] [An excellent article highlighting just how multifactorial sexual dysfunction is and the necessity for multimodal therapy.]

139. Perelman, M. Integrated sex therapy: a psychosocial-cultural perspective integrating behavioral, cognitive, and medical approaches.. In: Carson, CC.; Kirby, RS.; Goldstein, I.; Wyllie, MG., editors. Textbook of erectile dysfunction. 2nd ed.. Informa Healthcare; London: 2009. p. 298-305. 


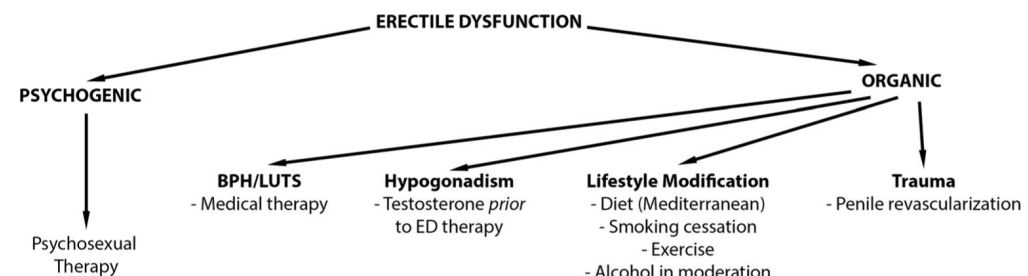

Therapy

Alcohol in moderatio

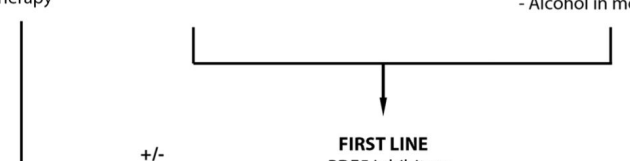

- PDE5 Inhibitors

- Vacuum Erection Device

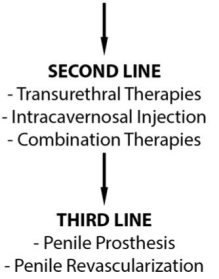

Fig. 1.

Treatment algorithm for erectile dysfunction 


\section{Table 1}

Types of ED and associated causes ${ }^{*}$

\begin{tabular}{|c|c|}
\hline Classification & Causes \\
\hline \multirow[t]{5}{*}{ Psychogenic } & Physical and mental health problems \\
\hline & Psychological trauma \\
\hline & Relationship problems/partner dissatisfaction \\
\hline & Family/social pressures \\
\hline & Depression \\
\hline \multicolumn{2}{|l|}{ Organic } \\
\hline \multirow[t]{2}{*}{ Neurologic } & Central nervous system—spinal cord injury, multiple sclerosis, stroke \\
\hline & Peripheral nervous system—neuropathy \\
\hline \multirow[t]{4}{*}{ Vasculogenic } & Arterial insufficiency/peripheral arterial disease \\
\hline & Veno-occlusive disease \\
\hline & Hypertension \\
\hline & Trauma \\
\hline \multirow[t]{5}{*}{ Medical disorders } & Hepatic insufficiency \\
\hline & Dyslipidemia \\
\hline & Renal insufficiency \\
\hline & Chronic obstructive pulmonary disease \\
\hline & Sleep apnea \\
\hline \multirow[t]{3}{*}{ Penile factors } & Cavernous fibrosis \\
\hline & Peyronie's disease \\
\hline & Penile fracture \\
\hline \multirow[t]{4}{*}{ Endocrine } & Hypogonadism \\
\hline & Hyperprolactinemia \\
\hline & Diabetes mellitus \\
\hline & Thyroid disorders \\
\hline \multirow[t]{2}{*}{ Urologic disorders } & Benign prostatic hypertrophy \\
\hline & Lower urinary tract symptoms \\
\hline \multirow[t]{5}{*}{ Drug-induced } & Antihypertensives \\
\hline & Antidepressants \\
\hline & Antiandrogens \\
\hline & Marijuana \\
\hline & Heroin \\
\hline \multirow[t]{3}{*}{ Iatrogenic } & Drug-induced \\
\hline & Postoperative \\
\hline & Postradiation \\
\hline
\end{tabular}




\section{Table 2}

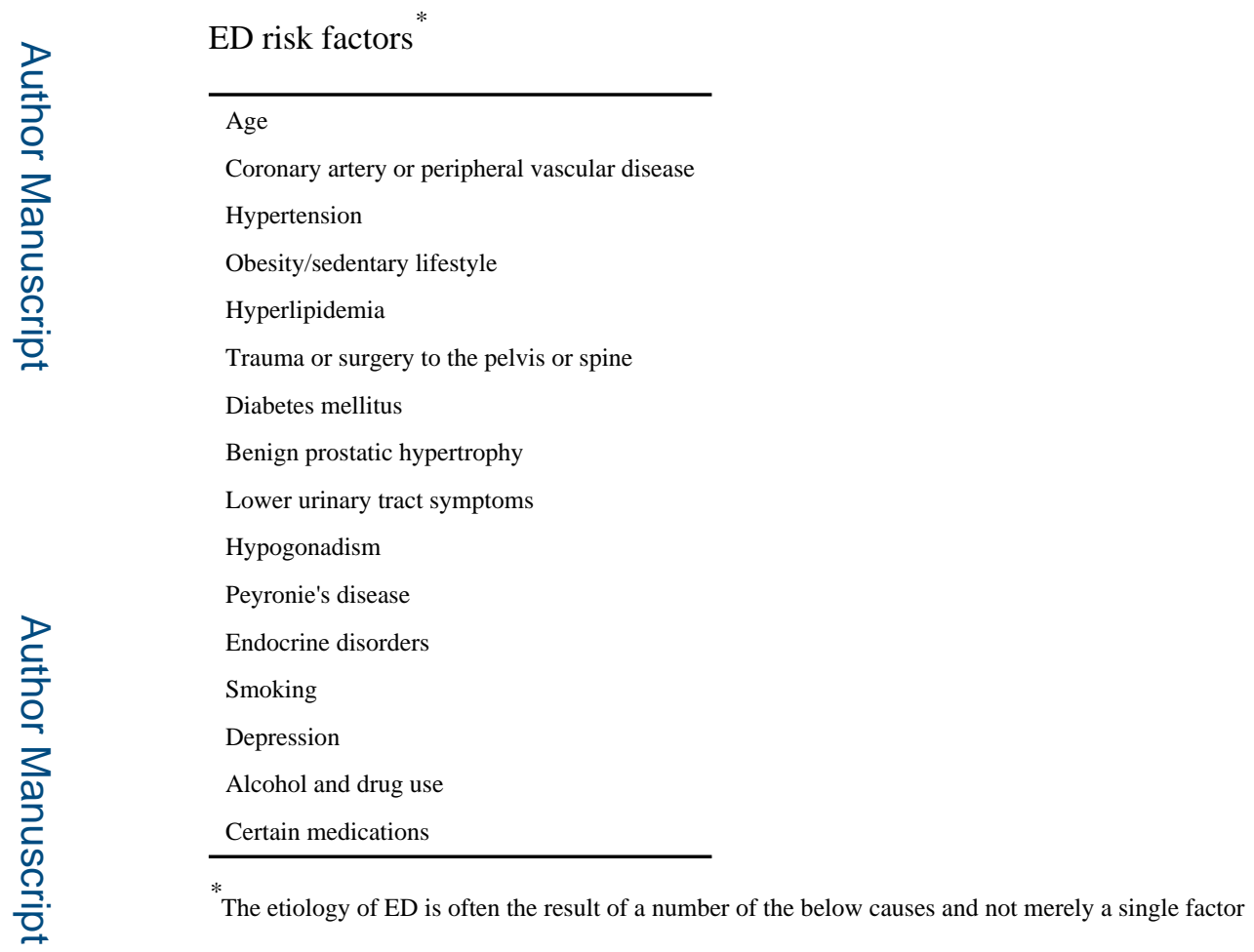




\section{Table 3}

\section{Laboratory tests recommended in evaluation for ED}

\begin{tabular}{l} 
Hemoglobin A1C \\
Hypothalamic-pituitary-gonadal axis evaluation \\
Testosterone \\
Free testosterone \\
Sex hormone-binding globulin \\
Prolactin \\
Luteinizing hormone \\
Follicle stimulating hormone \\
Lipid profile \\
Total cholesterol \\
HDL cholesterol \\
LDL cholesterol \\
VLDL cholesterol \\
Triglycerides \\
Thyroid function tests (if indicated) \\
Thyroid-stimulating hormone \\
Triiodothyronine (T3) \\
Total thyroxine (T4) \\
Free thyroxine (FT4) \\
\hline
\end{tabular}

